\title{
HUMAN RESOURCE COMPETENCIES IN THE ERA OF GLOBALIZATION
}

\author{
Onsardi $^{\mathrm{a}}$, Furqonti Ranidiah ${ }^{\mathrm{b}}$, Khairul Bahrun ${ }^{\mathrm{c}}$ \\ ${ }^{a b c}$ Economic Faculty of Muhammadiyah University of Bengkulu \\ a onsardi@umb.ac.id \\ ${ }^{\mathrm{b}}$ Furqonti.ranidiah@ gmail.com \\ ckhairulbahrun2014@gamil.com
}

\begin{abstract}
This article discusses the competence of human resources in the era of globalization. It is aimed to analyze competencies that human resources must have in facing the era of globalization. The method used in this research was literature study. Literature studies are used to find theoretical references that are relevant to cases or problems in a study. The results of this study indicate that competences needed by human resources in the era of globalization are (1) Critical thinking, (2) Ability to solve problems, (3) Communication and collaboration, (4) Creativity and innovation, (5) Information literacy, communication, and technology (ICT), (6) social and cross-cultural skills, (7) Ability to think of entrepreneurship, (8) Respect for diversity, (9) Teamwork and interconnectedness, (10) Civic and digital citizenship, and (11) religious competence. The whole competencies can be classsified into 5 core competencies, which are: (1) Communication competence both oral and written, (2) knowledge competence, (3) informational technology competence, (4) inter-cultural competence and (5) religious competence.
\end{abstract}

Keyword: Competence and globalization

\section{INTRODUCTION}

Discourses on the global era are still becoming a hot topic today. Everyone has various opinions about the topic. Some responded seriously, some responded ordinarily, and some other do not respond at all. In terms of globalization itself, it is not a new terminology because the Qur'an has explained it long ago, as Allah Subhanahu wa Ta'ala created humans to "globalize" in His word:

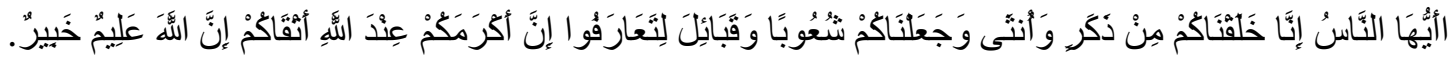

$O$ mankind, indeed We have created you from male and female and made you peoples and tribes that you may know one another. Indeed, the most noble of you in the sight of Allah is the most righteous of you. Indeed, Allah is Knowing and Acquainted ((Al-Hujuraat: 13)

To be able to take part in the era of globalization, of course, there are several competencies that must be possessed by human resources today. Globalization makes the world unlimited. Interaction between one country and another, individuals with individuals, companies group 
with companies group is becoming increasingly close without geographical boundaries. However, to be involved in the global era, human resources must have competences related to globalization itself. Interestingly, some of the study results those have been done indicate that Indonesia's human resources are still lacking in competences.

A study conducted by Trilling and Fadel (2009) shows that high school graduates, diplomas, and higher education were still less competent in terms of: (1) oral and written communication, (2) critical thinking and problem solving, (3) work ethics and professionalism, (4) team work and collaboration, (5) work in different groups, (6) use technology, and (7) project and leadership management. The 2014 ASEAN Business Outlook Survey also reports the results of its study that Indonesia was considered as a destination for foreign investment, and even becomes one of the main destinations in the ASEAN region. The survey also indicates an unfavorable fact that Indonesia has low-skilled and low-cost human resources.

Indonesia will not be able to compete and will lose good employment opportunities if it is not supported by particular program producing high competency graduates. Meanwhile, many new jobs based on production, analysis, distribution, marketing, and human resources and information systems are emerging. Along with changes in human lifestyles due to the presence of technology, workplaces become more computer-based and transforming. In contrary with the past, Indonesian graduates now need more competences to succeed in high competition of the global era. This is a challenge that must be addressed as best as possible (Siti Zubaidah, 2017).

What kind of competencies that must be possessed in order to be able to compete in the global era? Nowadays, there has been a significant shift from manufacturing services to services that emphasize information and knowledge (Scott, 2015a). The knowledge itself grows and extends significantly. Information and communication technology have changed the way we think, the nature of work that can be done, and the meaning of social relations. Joint decision making, sharing information, collaborating, innovating, and working speed are very important aspects at this time. Today, indicators of success are based more on the ability to communicate, share, and use information to solve complex problems, can adapt and innovate in response to new demands and change circumstances, and expand the power of technology to create new knowledge. 
New standards are needed so that later people will have the required competencies at the global era. Higher Education is challenged to find the ways to enable graduates to succeed in work and life by mastering creative thinking skills, flexible problem solving ability, and the readiness in collaborating and innovating. Some prior studies such as Trilling \& Fadel (2009), Ledward \& Hirata (2011), Partnership for 21Century Learning; The National Science Foundation, Educational Testing Services, NCREL, Metiri Group, Pacific Policy Research Center, and others confirm the importance of competencies in the global era to achieve the required transformation.

Various organizations have tried to formulate various kinds of competencies and skills needed in facing the global era. However, one important thing to note is that educating human resources in the global era cannot only be done through one approach only.

Wagner (2010) and Change Leadership Group from Harvard University identify 7 skills needed in life, the field of work, and citizenship in the global era, they are critical thinking and problem solving, collaboration and leadership, eficiency and adaptability, initiative and entrepreneurial spirit, ability to communicate both in oral and written, ability to access and analyze information, and possessing curiosity and imagination.

The US-based Apollo Education Group argues 10 skills, namely critical thinking, communication, leadership, collaboration, adaptability, productivity and accountability, innovation, global citizenship, ability and spirit of entrepreneurship, ability to access, analysis, and synthesizing information (Barry, 2012).

The US-based Partnership for 21st Century Skills (P21) identifies competencies needed in the global era called "The 4Cs", they are communication, collaboration, critical thinking, and creativity. These competencies are important to be taught to students in the context of core field of study and theme of the global era. Meanwhile, The Assessment and Teaching of 21st Century Skills (ATC21S) categorizes global era skills into 4, namely way of thinking, way of working, tools for working, and skills for living in the world (Griffin, McGaw \& Care, 2012). The way of thinking includes creativity, innovation, critical thinking, problem solving, and decision making. Way of working includes communication skills, collaboration and teamwork. Tool for working includes awareness as a global and local citizen, life and career development, and a sense of responsibility as a person and social. While skills for living in the world are skills that are based on information literacy, mastery 
of new information and communication technology, and the ability to learn and work through digital social networks.

In addition, Dwearto (2015) provides a religious view on competencies that human resources must have in the global era, they are religious competence, academic/intellectual competence, human social competence, and organizational competence. The purpose of this paper is to analyze the competencies that human resources must have in facing the era of globalization.

\section{METHOD}

The method used in this work is the study of literature. Literature studies are used to find theoretical references that are relevant to cases or problems in a study. These references can be searched from books, journals, research report articles, and sites on the internet. This type of study is mostly done to enrich references those are relevant to the problem.

\section{RESULT AND DISCUSSION}

\section{Critical Thingking Competence}

This competence is a fundamental skill in term of learning in the global era. It covered the meaning of the ability to access, analyze, and synthesize information that can be learned, trained and mastered (P21, 2007a; Redecker et al 2011). Critical thinking also describes other skills like communication and information skills, as well as the ability to examine, analyze, interpret, and evaluate evidence. In the era of digital literacy where the flow of information is very abundant, students need to have ability to choose relevant sources and informations, find qualified sources, and evaluate the sources on the aspect of objectivity, reliability, and currency.

\section{Problem Solving Comptence}

Problem solving skills includes ability to identify, search, select, evaluate, organize, and consider various alternatives and interpret information. One must be able to find various solutions from different perspectives in solving complex problems. Problem solving requires teamwork, effective collaboration and creative use of technology, good handling of a very large amount of information, ability to define and understand the elements contained in the subject matter, and ability to identify sources of information and strategies needed to solve problems. This competence also cannot be separated from critical thinking skills because it is 
very fundamental in solving problems. Students must also be able to apply most appropriate tools and techniques effectively and efficiently to solve problems.

\section{Communication and Collaboration}

The ability of doing communication are highly valuable ability in the work field and everyday life. Communication ability encompasses the ability in expressing thoughts clearly and persuasively through oral as well as writing, the ability in expressing opinions through clear sentences, conveying commands clearly, and motivating others through speaking capability. In the future world of work, collaborative skills ought to be applied when dealing with co-workers in locations that are far apart. Effective communication and collaboration skills accompanied by skills in using technology and social media will make it possible any occurrence of collaboration with international groups.

\section{Creativity and Innovation}

Creativity denotes to the ability to generate new things that has never been before. The process to produce those new things derives from imaginative processes from the creator himself, can also derive from information and previous experiences about things that will be created, afterwards the creator does merger and renewal of the work and ideas that have ever existed to produce new works and ideas, and they are different from existing works.

Professional and personal success accomplishment need the skill of innovation and creative spirit. Creativity and innovation will develop further if someone has opportunity to think critically. Everybody must be triggered to think outside the existing habits, involving new thinking ways, obtaining the chance to convey new ideas and solutions, proposing unusual questions, and trying to put alleged answers. Individual success will be achieved for those who have creative skills. Successful individuals will make this world becoming a better place for everyone.

\section{Information Literacy, Communication and Technology (ICT)}

ICT literacy capability cover the ability to access, organize, integrate, evaluate, and create information through digital communication technology uses. ICT Literacy is centered on high-level thinking skills in considering information, media, and technology in the surrounding environment. Every country should cause to emerge the ICT skills extensively in its community because if not, the country can fall behind the development and advancement 
of technology-based economic knowledge. There are several linkages between the three forms of literacy which comprise information communication literacy, media and technology. Mastery of these skills enables the mastery of the other skills and competencies needed for the success of life in the global era (Trilling \& Fadel, 2009).

\section{Social and Cross-Cultural Skills}

Good social and cross-cultural skills are very crucial in realizing success in life. These skills allow individuals to interact effectively with others (for example, knowing the right time to listen and talk, and how to treat yourself respectfully, professionally), to work in a team that has diverse members effectively (for example, respecting cultural differences and collaborating with people who derive from various social conditions and cultural backgrounds), to have open-minded of different ideas and values, and to use social and cultural differences to generate ideas, innovation and better quality work.

Possessing good social skills can assist in making a good decision. Good social skills for students and adolescents may influence their academic performance, attitudes, social and family relationships, and involvement in extracurricular activities. The ability to empathize also appertains social skills that are expected to grow in the life of the global era (National Research Council, 2012; P21, 2007a).

The ability to understand and communicate people across cultures or who have different cultures is a basic prerequisite in the world of work. All need to acquire intercultural competencies. For this reason, intercultural education, which aims at developing and improving these capabilities, can give contribution to maintaining inclusive peace and learning (Barrett et al., 2014). Intercultural competencies are not achieved automatically, but must be learned, practiced and maintained throughout life. Teachers play a very important role in facilitating the development of intercultural competencies among students (Barrett et al., 2014).

Mutual respect and tolerance attitudes are highly important to ensure that individuals views from all cultural backgrounds are admitted and respected in a multicultural society. The most notable thing is that students can learn to listen to others, show flexibility, and work with contributors in teams from various cultures and various scientific groups. This is a greatly essential competency and should not be missed by the global era society (Barrett et al, 2014). Based on the former statement, it is clear that education has a significant and even fundamental role in offering 
opportunities to students of the global era to evolve competencies that make it possible them to live peacefully with distinct cultural conditions (Carneiro and Draxler, 2008).

\section{The Ability to Think of Entrepreneurship}

Creativity and entrepreneurship thinking constitutes indispensable skills as well in the global era. Rapid employment growth and developing industries need the worker creativity, including the out of the box thinking ability, envisaging new scenarios and generating amazing works. Having an entrepreneurial mindset (the ability to recognize and take advantage of opportunities and capabilities to be responsible and take risks), allowing everybody to create jobs for him/herself and others. Consequently, students must be trained to respond questions and make decisions quickly. They also have to think smart and creative, observe and evaluate new opportunities and ideas. However, it is essential to note that these ideas must be beneficial or contribute a positive impact on the organization and community of residence or work. Entrepreneurial activities must be designed in such a way as to enable students to lead and cause to emerge greater autonomy $(\mathrm{P} 21,2008)$.

\section{Appreciating Diversity}

In the global era, students must actively take part in educational activities. Their active roles are able to help them to evolve competence in life and work together in communities that have a diversity of cultures and organizations. They must learn that they will not always be appreciated, but they ought to seek and use their talents and ideas among a variety of others.

These skills entangle deference and honor other people's problems and cultures that are different from their culture, so as they will achieve social and cross-cultural skills (Barrett et al., 2014). This also will raise awareness and knowledge about the differences that appear between individuals and society. The environment should bid the possibility to design learning activities that can provide chances for juvenile to respect, get along well and live side by side peacefully in an environment with a highly diverse culture (it is a life skill in global era that extremely honored). Hence, there is an urgent need for educators to devise collaborative learning activities and matching with obvious life which is able to expand understanding, skills and values. 


\section{Teamwork and Interconnectedness}

The survey results of Conference Board, 2006 (quoted by Scott, 2015b) detect that professionalism, good work ethics, oral and written communication, teamwork, collaboration, critical thinking and problem solving skills are highly important skills. These skills allow someone to obtain more value in the eyes of colleagues and thrive at once in a collaborative work environment (Redecker et al., 2011). Among the most crucial competency in the global era is the ability to aid interdisciplinary cooperation and the global ideas exchange to against discrimination potential for tribes, gender or age (Leis, 2010).

\section{Civic and Digital Citizenship}

Civic literacy, students are necessary to find out the rights and obligations of citizens in the local, regional and national scope; extend motivation, character and skills to take part in society; and understand the impact of community problems locally and globally (P21, 2013). Besides, other global era skill is digital citizenship (digital literacy community) namely grasping how to participate productively and responsibly online (P21, 2013). This is essential to aid students in apprehending how to participate smartly and ethically as responsible citizens in the virtual community. This thing involves learning about how to access the reliability and quality of information found on the internet and using information obtained responsibly (Davies, Fidler and Gorbis, 2011). Educational institutions are necessarily to set how students learn and practice using technology responsibly (for example ways how to access data, protection against things that are privacy, ways how to detect fraud, plagiarism, intellectual property rights and anonymity) and how to become good digital citizens.

\section{Religious Competence}

Students are necessarily to have the glory of aqeedah sourced from the Qur'an and the Sunnah of the Holy Prophet. Obedience to worship appointed in the Islamic Shari'a, have virtue and wisdom, is sincere in charity and worship.

\section{CONCLUSION}

From the former explanation, evidently, there are many competencies that must be mastered in the era of globalization. Furthermore, to become a competent human resource in the global era, certainly, you must prepare yourself with previous described competencies. Those competencies are 
the capital to achieve success in global business. From the various competencies, it can be concluded that to be the core competencies are: (1) Communication competence both oral and written, (2) knowledge competency , (3) information technology competency, (4) intercultural competency, and (5) religious competence

\section{REFERENCES}

Ananiadou, K. and Claro, M. 2009. 21st Century Skills and Competences for New Millennium Learners in OECD Countries. OECD Education Working Papers, No. 41. Paris, OECD Publishing.

Barrett, M., Byram, M., Lázár, I., Mompoint-Gaillard, P. and Philippou, S. 2014. Developing Intercultural Competence through Education. Pestalozzi Series No. 3. Strasbourg, Council of Europe Publishing.

Barron, B. and Darling-Hammond, L. 2008. Teaching for meaningful learning: a review of research on inquiry-based and cooperative learning. $\mathrm{L}$.

Barry, M. 2012. What skills will you need to succeed in the future? Phoenix Forward (online). Tempe, AZ, University of Phoenix.

Bialik, M. and Fadel, C. 2015. Skills for the 21st Century: What Should Students Learn? Center for Curriculum Redesign Boston, Massachusetts. www.curriculumredesign.org

Bolstad, R. 2011. Taking a 'Future Focus' in Education - What Does It Mean? NZCER Working Paper. Wellington, New Zealand Council for Educational Research.

Carneiro, R. and Draxler, A. 2008. Education for the 21 st century: lessons and challenges. European Journal of Education, Vol. 43, No. 2, pp. 149-160.

Cornell University Center for Teaching Excellence. 2014. Using Effective Questions (online). www.cte.cornell.edu/teaching-ideas/engaging-students/using-effectivequestions.html

Darling-Hammond, B. Barron, P.D. Pearson, A.H. Schoenfeld, E.K. Stage, T.D. Zimmerman, G.N. Cervetti and J.L. Tilson (eds), Powerful Learning: What We Know About Teaching for Understanding. San Francisco, Calif., Jossey-Bass/John Wiley \& Sons.

Davies, A., Fidler, D. and Gorbis, M. 2011. Future Work Skills 2020. Palo Alto, Calif., University of Phoenix Research Institute.

Delors, J., Al Mufti, I., Amagi, I., Carneiro, R., Chiung, F., Geremek, B., Gorham, W., Kornhauser, A., Manley, M., Padrón Quero, M., Savané, M-A., Singh, K., Stavenhagen, R., Won Suhr, M. and Nanzhao, Z. 1996. Learning: The Treasure Within: Report to UNESCO of the International Commission on Education for the Twenty-First Century. Paris, UNESCO.

Furlong, J. and Davies, C. 2012. Young people, new technologies and learning at home: taking context seriously Oxford Review of Education, Vol. 38, No. 1, pp. 45-62.

Griffin, P., McGaw, B. and Care, E. (eds). 2012. Assessment and Teaching of 21 st Century Skills. Dordrecht, NL, Springer.

Hampson, M., Patton, A. and Shanks, L. 2011. Ten Ideas for 21st Century Education. London, Innovation Unit. 
Herring, S. 2012. Transforming the workplace: critical skills and learning methods for the successful 21st century worker. Big Think (online). http://bigthink.com/expertscorner/transforming-the- workplace-critical-skillsandlearning-methods-for-the-successful-21st-century-worker.

Nichols, J. 2013. 4 Essential Rules of 21st Century Learning. [Online]. Tersedia di: http://www.teachthought.com/learning/4-essential-rules-of-21stcentury-learning/. Diakses 5 Desember 2016.

Lai, E.R. 2011. Metacognition: A Literature Review. Pearson Research Report. Upper Saddle River, NJ Pearson Education.

Leadbeater, C. 2008. What's Next? 21 Ideas for 21st Century Learning. London, The Innovation Unit.

Ledward, B. C., and D. Hirata. 2011. An overview of 21st century skills. Summary of 21st Century Skills for Students and Teachers, by Pacific Policy Research Center. Honolulu: Kamehameha Schools-Research \& Evaluation.

Leis, M. 2010. Challenges for the Future of Learning until 2030: Foresight on Learning, Innovation and Creativity. Presentation at LearnTec 2010, Karlsruhe, DE.

Mansilla, V.B. and Jackson, A. 2011. Global Competence: Preparing Our Youth to Engage the World. New York, Asia Society.

McLoughlin, C. and Lee, M.J.W. 2008. The three p's of pedagogyfor the networked society: personalization, participation, and productivity. International Journal of Teaching and Learning in Higher Education, Vol. 20, No. 1, pp. 10-27.

Meyer, B., Haywood, N., Sachdev, D. and Faraday, S. 2008. Independent Learning: Literature Review. Research Report No. DCSF-RR051. Nottingham, UK, Department for Children, Schools and Families.

National Research Council. 2012. Education for Life and Work: Developing Transferable Knowledge and Skills in the 21st Century. Washington DC, National Academies Press.

P21. 2007a. The Intellectual and Policy Foundations of the 21st Century Skills Framework. Washington DC, Partnership for 21st Century Skills.

P21. 2007b. 21st Century Curriculum and Instruction. Washington DC, Partnership for 21st Century Skills.

P21. 2008. 21st Century Skills, Education \& Competitiveness. Washington DC, Partnership for 21 st Century Skills.

P21. 2011. Framework for 21st Century Learning. Washington DC, Partnership for 21st Century Skills.

P21. 2013. Reimagining Citizenship for the 21st Century: A Call to Action for Policymakers and Educators. Washington DC, Partnership for 21st Century Skills.

Pacific Policy Research Center. 2010. 21st Century Skills for Students and Teachers. Honolulu: Kamehameha Schools, Research \& Evaluation Division.

Redecker, C., Ala-Mutka, K., Leis, M., Leendertse, M., Punie, Y., Gijsbers, G., Kirschner, P., Stoyanov, S. and Hoogveld, B. 2011. The Future of Learning: Preparing for Change. Luxembourg, Publications Office of the European Union. 
Saavedra, A. and Opfer, V. 2012. Teaching and Learning 21st Century Skills: Lessons from the Learning Sciences. A Global Cities Education Network Report. New York, Asia Society.

Scott, C.L. 2015a. The Futures of Learning 1: Why must learning content and methods change in the 21st century? UNESCO Education Research and Foresight, Paris. [ERF Working Papers Series, No. 13].

Scott, C.L. 2015b. The Futures of Learning 2: What kind of learning for the 21st century? UNESCO Education Research and Foresight, Paris. [ERF Working Papers Series, No. $14]$.

Scott, C.L. 2015c. The Futures of Learning 3: What kind of pedagogies for the 21st century? UNESCO Education Research and Foresight, Paris. [ERF Working Papers Series, No. 15].

Siti Zubaidah, 2017. Keterampilan Abad Ke-21: Keterampilan Yang Diajarkan Melalui Pembelajaran. Conference Paper. Universitas Negeri Malang.

Trilling, B. and Fadel, C. 2009. 21st Century Skills: Learning for Life in Our Times. San Francisco, Calif., Jossey-Bass/John Wiley \& Sons, Inc.

Wagner, T. 2010. Overcoming The Global Achievement Gap (online). Cambridge, Mass., Harvard University.

Woods, D. 2014. Problem-Based Learning (PBL) (online). McMaster University. http://chemeng.mcmaster.ca/problembased-learning (Diakses 5 DesembeR 2016). https://www.academia.edu/6215005/_Globalisasi_dalam_Islam_ http://dwearto.blogspot.com/2015/06/4-kompetensi-sdm-di-era-globalisasi.html 